\title{
Multivariate analysis of soil salination-desalination in a semi-arid irrigated district
} of Spain

\section{J.L. Mora ${ }^{\text {a }}$, J. Herrero ${ }^{\text {b*, D.C. Weindorf }}{ }^{\mathrm{c}}$}

5 a Departamento de Ciencias Agrarias y del Medio Natural, Universidad de Zaragoza. c/ Miguel Servet 177; 50013 Zaragoza, Spain

b Estación Experimental Aula Dei, CSIC. Av. Montañana 1005; 50059 Zaragoza, Spain

c Department of Plant and Soil Science, Texas Tech University; Lubbock, TX 79409, USA

E-mail addresses: jlmorah@unizar.es (J.L. Mora), jhi@eead.csic.es (J. Herrero), david.weindorf@ttu.edu (D.C.Weindorf)

\section{ABSTRACT}

Long-term studies of the changes in soil salinity are scarce and most overlook individual ions. Here, we assess changes in soil ionic contents using 42 soils repeatedly sampled during three campaigns over 24 years in a semi-arid irrigated district. Multivariate analysis (MVA) was used to evaluate the spatial distribution of ions and the temporal changes at comparable soil depths in relation to environmental and management factors. In general, the position of the soil in the landscape governed the spatial distribution of the salinity, while the temporal variations were related to irrigation, with incidences depending on the location in the district. Many soils on the slopes and foothills became salinated during the first years due to land leveling, but salination eventually tapered off after sprinkler utilization. At high and middle elevations, most soils were slightly saline in the first campaign but underwent desalination during the study period. At lower elevations, an initial desalination was followed by a pronounced salination, which was attributed to a water table rise with generalized irrigation in the basin. Whereas univariate salinity assessment might lead to conclusions that are over-simplistic at the landscape scale, MVA detects singular 
30 behaviors of groups of soils or single cases and has enormous potential coupled with GIS assessment of soil salinity data.

Keywords: Irrigation, salt-affected soils, soil salinity, soil sodicity.

Abbreviations: ECe, electrical conductivity of the saturation extract; GIS, geographic information system; MVA, multivariate analysis; PCA, principal components analysis; RDA, redundancy analysis; SAR, sodium adsorption ratio.

\section{Introduction}

Soil salinity and sodicity are the two major concerns in irrigated agriculture in dry regions of the world, and they are increasing worldwide due to poor management of water and soil resources (Shahid, 2013). Periodic information on the status of soil salinity and sodicity in irrigation districts can suggest management practices and corrective measures to improve the profitability and sustainability of irrigated agriculture (Young, 1991; Rhoades et al., 1997; Herrero et al., 2011).

Temporal monitoring of soil salinity is mainly based on the comparison of pointsize data for several years (regular observations and sampling in the same point) or on the comparison of soil salination maps developed in different years (Rhoades et al., 1997; Rukhovich et al., 2013). The standard method for appraising agricultural salinity is to measure the electrical conductivity of a saturated soil paste extract (ECe $-\mathrm{dS} \mathrm{m} \mathrm{m}^{-1}$ ) following the United States Salinity Laboratory Staff (1954) approach. This extract can be used to determine the $\mathrm{pH}$ and the ionic composition of the soil solution. Focus is set on the concentration of undesirable ions, e.g., high contents of chloride $\left(\mathrm{Cl}^{-}\right)$which causes toxicity in plants. Attention is also paid to the relationships between ions, e.g., the ratio of sodium $\left(\mathrm{Na}^{+}\right)$to calcium $\left(\mathrm{Ca}^{2+}\right)$ and magnesium $\left(\mathrm{Mg}^{2+}\right)$, as expressed by the sodium adsorption ratio (SAR), which has long been the standard measure of potential sodication hazard for irrigated soils (United States Salinity Laboratory Staff, 1954). In recent decades, soil salinity and sodicity has been indirectly monitored through its expression on vegetative cover using remote sensing (Metternicht and Zinck, 2009; Domínguez-Beisiegel et al., 2016) or proximal sensors (Amezketa, 2007; Corwin, 2008; 
60 Herrero et al., 2011; Swanhart et al., 2014; Aldabaa et al., 2015;). Studies addressing the temporal variation in the ionic composition of soil solutions are much less abundant. Most of these studies are based either on laboratory analyses of soil samples taken at different times (Pisinaras et al., 2010; Corwin, 2012; Ammari et al., 2013) or on chronosequences of soil use (Barbiéro et al., 2004; Dou et al., 2011).

Monitoring soil salinity is difficult due to its spatial and temporal variability and is complicated by management practices, such as irrigation, drainage, and plowing; by weather, and by the salinity and depth of water tables (Herrero and Snyder, 1997; Rhoades et al., 1997; Akramkhanov et al., 2011). The multivariate nature of ionic composition makes monitoring more difficult, often resulting in different variation patterns for each particular ion or ionic ratio. In this regard, multivariate analysis (MVA) can be very useful because this technique can simplify multivariate datasets (e.g., ionic composition) without a substantial loss of information. It also allows for handling of complex and often highly collinear matrices of data, as is often the case in soil studies, and accounting for the effects of environmental and management variables (Johansson and Stenberg, 2000; Young and Hammer, 2000). There are three main classes of MVA which are used in environmental analyses: (i) cluster analysis, in which the observations are assigned into groups (clusters) on the basis of their similarity; (ii) indirect gradient analysis, such as principal components analysis (PCA), which ranks observations along variation axes that represent gradients derived from intrinsic and/or environmental factors; and (iii) direct gradient analysis, such as the redundancy analysis (RDA) in which a second set of explanatory variables is incorporated to ordination, and the effects of this set on the original variables are evaluated by regression techniques (Legendre and Legendre, 2012). Cluster and indirect gradient analysis are commonly used when studying the ionic composition of soil solutions (e.g., Mora et al., 2005;

85 Aguilera et al., 2011), while direct gradient analysis has been used to study the effects of the ionic composition of soil solutions on vegetation (Álvarez Rogel et al., 2001; Rodríguez et al., 2005; Tug et al., 2012). However, direct gradient analysis has not been used frequently to study the environmental or management factors responsible for the spatial variability in the ionic composition of soil solutions. To our knowledge, no works are available that use all of these tools to examine the temporal variation in soil salinity. 
In the present article, MVA (i.e., PCA, RDA, and cluster analysis) was used to analyze salinity (i.e., ECe) and sodicity/alkalinity (SAR, pH) indices as well as the salt composition (e.g., $\mathrm{Na}^{+}, \mathrm{Ca}^{2+}+\mathrm{Mg}^{2+}$ ) of soil solutions, in a semi-arid irrigation district using data collected at three time steps (i.e., 1975, 1985/1986, and 1999). Our aim was to determine the usefulness of MVA to discern the temporal impact of environmental (e.g., landscape position) and management (e.g., land use) factors on the soil salt composition over this period.

\section{Methods}

\subsection{Study area}

The study was conducted in the irrigated district of Flumen, located in the Ebro basin of north-east Spain, between $41^{\circ} 40^{\prime}$ and $42^{\circ} 5^{\prime} \mathrm{N}$, and $0^{\circ} 0.5^{\prime}$ and $0^{\circ} 35^{\prime} \mathrm{W}$. The Flumen district is representative of the changes produced by irrigation in the semiarid middle Ebro Basin. In this area, salinity mostly stems from the weathering of the saliferous Miocene strata, which were often brought to the surface by the movement of soil needed to establish new irrigation districts in the middle $20^{\text {th }}$ century. Currently, a significant amount of irrigated lands in the Ebro Basin are salt-affected, despite that, in the last decades, drip and sprinkler irrigation using water of low ionic content has driven the abatement of water tables and the desalination of many soils. The abatement of the salt-affection of soils in Flumen between 1975 and 1999, with a more pronounced trend in more saline soils, was reported by Herrero and Pérez-Coveta (2005); however, examining the changes in the ionic composition remained outside the scope of that study.

The studied area is bound by the rivers Flumen and Alcanadre and by the Flumen Canal (Figure 1). The area is $263 \mathrm{~km}^{2}$ (including non-agricultural lands). The elevation ranges from $260 \mathrm{~m}$ to $400 \mathrm{~m}$ above sea level with an overall decrease from $\mathrm{N}$ to $\mathrm{S}$. The climate is Mediterranean semiarid; the mean-annual precipitation is $423 \mathrm{~mm}$ and the mean-annual temperature is $14.5{ }^{\circ} \mathrm{C}$ (Herrero and Pérez-Coveta, 2005). The potential evapotranspiration ( $\mathrm{ET}_{0}$ ) has an annual value of approximately $1150 \mathrm{~mm}$ according to the FAO Blaney-Criddle method, with the $\mathrm{ET}_{0}$ exceeding precipitation from February to October (Marínez-Cob et al., 1998). In these conditions, irrigation practices began at least 600 years ago at the riverbanks and were extended to include most of the land in the 1950's. The main crops are alfalfa (Medicago sativa L.), barley (Hordeum vulgare 
L.), forage (Lolium multiflorum Lam.), corn (Zea mays L.), rice (Oryza sativa L.), sunflower (Helianthus annuus L.), and wheat (Triticum aestivum L.). The traditional controlled flood basin and border irrigation is gradually being changed to sprinkling, except the rice paddies, which are inundated from May to September. Most water comes from reservoirs in the Pyrenees, and its ionic contents are low with an electrical conductivity $<0.4 \mathrm{dS} \mathrm{m}^{-1}$ and an SAR $<1\left(\mathrm{mmol} \mathrm{L}^{-1}\right)^{-0.5}$ (Nogués et al., 2000; Herrero and Pérez-Coveta, 2005). Following the FAO guidelines (Ayers and Westcot, 1994), such low electrical conductivity poses no salinity hazard but may cause slight to moderate infiltration problems, even though the SAR is low.

The geological materials are subhorizontal Miocene strata of alternating sandstone and lutite, the latter being often saliferous. The main landforms are platforms (A), slopes (B), terraces (C), and valley bottoms (D) (Table 1), and the characteristics of the soils on the different landforms are very different. The calcium carbonate content of the soils is always $>25 \%$. Saline soils are common in several landform units (B1, B2, C2, C3, C4, and D), but saline-sodic soils occur only in spots at C3, C4, and D (Nogués et al., 2000; Nogués and Herrero, 2003).

\subsection{Sampling design and field work}

The soil samples in this study were taken from soils cultivated under irrigation in three sampling campaigns. The first campaign was between June 26 and August 20, 1975; the second was from July 19, 1985 to June 16, 1986; and the third was between April 19 and May 15, 1999. The soil sampling campaign in 1975 was designed by INYPSA (Informes y Proyectos, S.A., Madrid, Spain), a consulting company contracted by the Spanish Government. The aim of the 1975 campaign was to serve as the base of a soil map intended for the development of the irrigated district, and the results were recorded and discussed in an unpublished report. The second and third campaigns were designed and performed by one of the authors (J.H.) to appraise the evolution of saltaffected soils. For this purpose, the strategy was to relocate and resample the sites that were sampled in 1975, using the 1975 campaign as a baseline set of data. The sites were re-sampled using an auger. Several of the sites from 1975 were excluded in the successive samplings because the documentation from 1975 made the sites difficult to 
155 locate or because the results of the analyses were illegible due to the degradation of the 1975 report.

More details about the study sites selection and field work can be found in Herrero and Pérez-Coveta (2005). In the present study, we considered only those sites where the sampling depth was considered sufficient in the three campaigns, which made 42 sites (of the 66 sites studied by Herrero and Pérez-Coveta (2005)).

\subsection{Laboratory data}

All soil analyses were performed on the fine earth fraction obtained after airdrying the samples and passing them through a $2 \mathrm{~mm}$ sieve. The soil analyses performed for the three sampling campaigns were $\mathrm{pH}$ in water and potassium chloride $(\mathrm{KCl})$, electrical conductivity of the saturated soil paste extract (ECe), and determining the ion concentrations of $\mathrm{Cl}^{-}, \mathrm{Na}^{+}$, and $\left(\mathrm{Ca}^{2+}+\mathrm{Mg}^{2+}\right)$ in each extract. In the second and third sampling campaigns, sulfate $\left(\mathrm{SO}_{4}{ }^{2-}\right)$, bicarbonate $\left(\mathrm{HCO}_{3}{ }^{-}\right), \mathrm{Ca}^{2+}$, and $\mathrm{Mg}^{2+}$ were also titrated. Chemical determinations were performed per the official methods of the Spanish Ministry of Agriculture (MAPA, 1974, 1994), with some adaptations (Table 2) related to advances in laboratory equipment. As discussed in the paper by Herrero and Pérez-Coveta (2005), the high quality and coherence of the analytical results from the three sampling campaigns allowed for comparisons between these results, with some indicated exceptions.

\subsection{Data processing}

At many sites, the sampling depth or the depth intervals were not consistent between the three sampling campaigns, thus making a direct comparison between sampling dates unsound. To overcome this, a comparable soil depth was selected for each soil to compare the data obtained at different campaigns. For all sites where a $1 \mathrm{~m}$ depth was attained, we used this depth as the comparable depth. According to Herrero (1987), the average salt content of the upper meter of the soil is almost constant during a single year; moreover, this soil layer contains the roots of most cultivated plants and is thus related to the effects of salinity on crops. At the sites where the sampling depth was 
185 between $0.8 \mathrm{~m}$ and $1.0 \mathrm{~m}$, we used the minimum attained depth as the comparable depth. For soils with similar shallow sampling depths in the three campaigns, we also used the minimum depth as comparable depths.

After determining the comparable depth for each sampling site, we calculated a comparable value for ECe, $\mathrm{pH}$, and ionic contents in the saturation extract, i.e., an 190 averaged value for the soil between the surface and the comparable depth. The comparable values were calculated for each site and sampling date per Eq. 1:

$$
X_{\text {comp }}=D^{-1} *\left[\sum X_{i} * d_{i}-X_{n} *\left(\sum d_{i}-D\right)\right]
$$

where $X_{\text {comp }}$ is the comparable value of the studied property, $D$ is the comparable depth, $X_{i}$ is the value of this property in the $i$-th sample from the surface, $d_{i}$ is the thickness of the $i$-th sample, and $n$ is the first of the successive samples whose lower limit is $\leq$ the comparable depth. The comparable values were calculated using the software Slices version 1 (http://hdl.handle.net/10261/60892). To avoid averaging the $\mathrm{pH}$ measures (which is senseless from an arithmetic point of view), we transformed $\mathrm{pH}$ into the concentration of hydrogen ions $\left[\mathrm{H}^{+}\right]$expressed as mol $\mathrm{L}^{-1}$ and then calculated the 200 comparable $\left[\mathrm{H}^{+}\right]_{\text {comp. }}$. For ease of interpretation, the $\left[\mathrm{H}^{+}\right]_{\text {comp }}$ was back transformed to a logarithmic scale, obtaining the $\mathrm{pH}_{\text {comp }}$.

The sodicity was evaluated by calculating the SAR for each analyzed horizon per Eq. 2:

$$
S A R=\frac{N a^{+}}{\sqrt{\frac{1}{2} *\left(C a^{2+}+M g^{2+}\right)}}
$$

205 We considered that the undesirable effects of SAR were best represented by the maximum SAR recorded in the profile than by an averaged SAR. Thus, for each soil and sampling date, we compared the maximum SAR value of the horizons within the comparable depth $\left(\mathrm{SAR}_{\mathrm{comp}}\right)$.

Changes in the investigated soil properties were measured per the relative 210 variation of the comparable values per Eq. 3:

$$
\Delta X_{t 1-t 2}=\frac{X_{\text {comp }}(t 1)-X_{\text {comp }}(t 2)}{X_{\text {comp }}(t 1)}
$$


where $X_{\text {comp }}(t 1)$ and $X_{\text {comp }}(t 2)$ are the comparable values of the studied property at the beginning ( $t 1)$ and end ( $t 2)$ of the considered period. In this way, we calculated the relative variations in the comparable values of $\mathrm{ECe}, \mathrm{SAR}, \mathrm{Cl}^{-}, \mathrm{Na}^{+}$, and $\mathrm{Ca}^{2+}+\mathrm{Mg}^{2+}$ that occurred between the three campaigns. We also calculated the variations for $\mathrm{Ca}^{2+}$, $\mathrm{Mg}^{2+}, \mathrm{SO}_{4}{ }^{2-}, \mathrm{HCO}_{3}{ }^{-},\left[\mathrm{H}^{+}\right]$-water, and $\left[\mathrm{H}^{+}\right]-\mathrm{KCl}$ from the second to the third campaign. The $\mathrm{pH}$ values from the first campaign were disregarded for these calculations due to uncertainty in the soil dilutions used in the laboratory (Table 2).

\subsection{Statistical analysis}

Several environmental and management factors were examined in relation to their influence on soil ionic composition. Thus, we considered the elevation (meters above sea level), the location of the soils in the landscape units, rice cropping in 1990 and 2000 and the productive intensity according to the Cadaster Service of Spain. The landscape units, described in Table 1, included the following: structural platforms (A1A2), slopes (B1-B2), terraces (C1-C4), and bottoms (D). The rice paddies were separated from the other irrigated crops using the System of Territorial Information of Aragon (http://sitar.aragon.es/; accessed May 2016) that was based on the CORINE Landcover maps at level 3 from 1990 and 2000, which were considered approximate proxies for rice cropping in 1986 and 1999, respectively. The productive intensity was based upon the land capacity for crop production, which is attributed to each site by the Cadaster Service of Spain (https://www1.sedecatastro.gob.es/; accessed May 2016) and based on actual crop use. Landscape units and rice cropping were coded as dummy variables $(1=$ yes, $0=$ no $)$ for their use in PCAs and RDAs.

We used a PCA of the laboratory data of the three sampling campaigns to investigate the relationships between the soil ionic components and their consistency over time. Prior to analysis, the data were centered and standardized by standard deviation. Environmental (elevation, landscape unit) and management (rice cropping, productive intensity) factors were entered into the PCA as supplementary variables (not affecting the ordination but allowing an appraisal of their relationship with the soil solution composition).

A similar centered and standardized PCA was performed on the relative variations of the ionic contents of the soils to study the patterns of temporal variation between the first and second campaigns and between the second and third campaigns. The scores of 
the three first principal components were used as the base of a cluster analysis, which was based on the K-means method and squared Euclidean distance and intended to construct groups of soils showing coincident temporal variation. Previously, we used Ward's hierarchical technique to provide the K-means algorithm with the optimum number of clusters, following Hair et al. (2010).

The RDA can be used as a regression technique for multivariate data (Legendre and Legendre, 1998). We used RDAs to determine how much of the variance in (a) the soil solution composition and (b) the variations that occurred in the two periods (first to second and second to third campaigns), can be explained by a set of explanatory variables, including environmental and management factors. In each case, from the full set of explanatory variables, i.e., elevation, landscape unit (A1, A2, B1, B2, C1, C2, C3,

255 C4, and D) and landscape unit type (platforms, slopes, terraces, and bottoms, respectively, A, B, C, and D), rice cropping in 1990 and 2000, and productive intensity, the best minimum set of explanatory variables was selected by a forward stepwise procedure, using Monte Carlo tests with 1,000 permutations. This procedure enabled us to include only those factors with a significant $(P<0.10)$ contribution to variance and discard the remaining factors with less explanatory power or with redundancy. The statistical significance of the first axes and all canonical axes obtained were also determined by Monte Carlo tests (1,000 permutations).

The PCAs and RDAs were conducted with Canoco for Windows version 4.5 (Microcomputer Power, Ithaca, NY). Cluster analyses were performed with SPSS Statistics version 19 (SPSS Inc., Chicago, IL).

\section{Results}

\subsection{General features of the soil solution composition}

\subsubsection{Salinity and sodicity/alkalinity status}

Figure 2 shows the frequency distributions of $\mathrm{ECe}_{\text {comp }}, \mathrm{pH}-$ water $_{\text {comp }}, \mathrm{pH}-$ $\mathrm{KCl}_{\text {comp }}, \mathrm{Cl}^{-}{ }_{\text {comp }}, \mathrm{Na}^{+}$comp, $\left(\mathrm{Ca}^{2+}+\mathrm{Mg}^{2+}\right)_{\text {comp }}$, and $\mathrm{SAR}_{\text {comp }}$ in the three soil sampling campaigns, and those of $\mathrm{SO}_{4}{ }^{2-}$ comp and $\mathrm{HCO}_{3}{ }^{-}$comp in the second and third campaigns. Comparing the comparable values of ECe, SAR and $\mathrm{pH}$ with the threshold values set by 
the United States Salinity Laboratory Staff (1954), the soils can be described as mostly non- or very slightly saline (ECe $<4 \mathrm{dS} \mathrm{m}^{-1}$ ), not or very slightly sodic (SAR $<13$ $\left.\left.(\mathrm{mmol} \mathrm{L})^{-1}\right)^{-0.5}\right)$, and moderately or strongly alkaline $(7.9<\mathrm{pH}<9.0)$ for the three campaigns.

\subsubsection{Main gradients in the soil solution composition}

Figure 3 shows the results of the PCA carried out on the soil solution data of the three sampling campaigns. The factor loadings of the soil solution components and of the explanatory (environmental and management) factors and the scores of the individual soils on the four first axes are displayed. Based on these results, the following can be seen:

- Axis I had large positive loadings (Figure 3a, right half) for $\mathrm{ECe}, \mathrm{Cl}^{-}, \mathrm{SO}_{4}{ }^{2-}$, and $\mathrm{Na}^{+}$and represents the major gradient of salinity. The distribution of the soils along this axis was conspicuously related to their landscape position. Thus, most soils of the terraces (units C1-C4) had large positive scores (Figure 3a, on the right) corresponding to high salinity levels, while the soils from the platforms (units A1 and A2) had the lowest scores (Figure 3a, left) and salinity. The soils from the slopes and bottoms (units B1, B2, and D) showed intermediate scores (Figure 3a, center) and salinity levels.

- $\quad$ Axis II had positive loadings (Figure 3a, top) for $\mathrm{pH}$-water, $\mathrm{pH}-\mathrm{KCl}, \mathrm{HCO}_{3}{ }^{-}$, and SAR and was therefore considered a representation of sodicity-alkalinity. Rice cropping in 1990 and 2000 showed large loadings on axis II, and a position in the diagram close to those of SAR and $\mathrm{pH}$. This finding mirrors the location of rice crops on sodic/alkaline soils.

- Remarkably, the loadings on axes I and II for the same soil properties measured in the different sampling campaigns (1975, 1985/86, and 1999) appeared generally plotted close to each other. This result mirrors both a general agreement in the salinity distribution patterns across different dates and a high temporal consistency of the analytical methods.

- In contrast, axes III and IV (Figure 3b) accounted for variation in the soil solution composition that was specific to each the sampling dates. Thus, axis III had large negative loadings (Figure 3b. left) for the $\mathrm{ECe}, \mathrm{Cl}^{-}, \mathrm{HCO}_{3}{ }^{-}, \mathrm{Na}^{+}, \mathrm{Ca}^{2+}$, $\mathrm{Mg}^{2+}$, SAR, and $\mathrm{pH}-\mathrm{KCl}$ measurements from the second sampling campaign. 
Conversely, axis IV had notable positive loadings (Figure 3b, top) for ECe, $\mathrm{Cl}^{-}$, $\mathrm{SO}_{4}{ }^{2-}, \mathrm{HCO}_{3}{ }^{-}, \mathrm{Na}^{+}, \mathrm{Ca}^{2+}$, and SAR from the third campaign, and corresponding negative loadings (Figure 3b, bottom) for the measurements for $\mathrm{ECe}, \mathrm{Cl}^{-}, \mathrm{Na}^{+}$, $\mathrm{Ca}^{2+}+\mathrm{Mg}^{2+}$, and SAR from the first campaign.

\subsubsection{Main factors affecting the soil ionic composition}

According to the RDA, the soil solution composition was mainly determined by the location at the valley bottoms (units C1-C4) $(P<0.01)$ and the rice cropping in 1999 $(P<0.10)$. The other environmental and management factors were less relevant or redundant $(P>0.10)$. An ordination model based on these two factors was statistically significant ( $P<0.05$ for the first canonical axis as well as for the first two axes), despite having a low explanatory power for the soil solution composition $(10.1 \%$ of the variance explained).

\subsection{Temporal variations of the soil solution composition}

\subsubsection{Overall temporal trends in salinity and sodicity}

A general trend towards lower ECe $\mathrm{E}_{\text {comp }}$ with time was apparent (Figure 2a) that was consistent with that observed by Herrero and Pérez-Coveta (2005). Accordingly, there were increases over time in the number of soils with lower $\left(<8 \mathrm{mEq} \mathrm{L}^{-1}\right)$ values of $\mathrm{Cl}^{-}$comp (Figure 2d), $\mathrm{SO}_{4}{ }^{2+}$ comp (Figure 2e), $\mathrm{Na}^{+}{ }_{\text {comp }}$ (Figure $2 \mathrm{~g}$ ), and $\left(\mathrm{Ca}^{2+}+\mathrm{Mg}^{2+}\right)_{\text {comp }}$ (Figure 2h). Furthermore, Figures $2 \mathrm{~b}$ and 2c show a gradual shift in $\mathrm{pH}$-water ${ }_{\text {comp }}$ and $\mathrm{pH}-\mathrm{KCl}_{\text {comp }}$ from a preponderance of soils in the lower $\mathrm{pH}$ ranges in the first campaign to a greater number of soils in the higher $\mathrm{pH}$ ranges in the third campaign. A marked increase was also observed in the number of soils with extreme values of $\operatorname{SAR}_{\text {comp }}(<5$ and $\left.>45\left(\mathrm{mmol} \mathrm{L}^{-1}\right)^{-0.5}\right)$ from the first to the second campaigns (Figure 2i), which was a consequence of a larger increase in $\mathrm{Na}^{+}$comp compared to $\left(\mathrm{Ca}^{2+}+\mathrm{Mg}^{2+}\right)_{\text {comp }}$ in these ranges.

\subsubsection{Multivariate patterns of the temporal changes}

Figure 4 displays the results of the PCA of the relative variations of the soil solution components from the first to the second campaigns and from the second to the third campaigns. The loadings of these variations and the scores of the studied soils are plotted for the first three PCA axes. The loadings of the variations from the first to the 
third campaigns and of the environmental and management factors are also represented as supplementary variables. A legend is provided to show the membership of the soils in the clusters obtained from the first three PCA axes. Since these axes represent the major gradients of variation within the temporal variation data, clustering was considered to help distinguish groups of soils with coinciding temporal trends. From these results, the following was observed:

- Axis I had positive loadings (Figure 4a, right) for the variations from the first to the second sampling campaigns, and negative loadings (Figure 4b, left) for most of the variations from the second to the third campaign. As seen from these opposite trends, those soils showing positive scores on axis I tended to increase their salinity levels from the first to the second campaigns and decrease their salinity from the second to the third campaigns, and the reverse was the case for the soils with negative scores on this axis. The largest positive scores on axis I were for a group of soils (cluster II) that are plotted close to productive intensity and location in slopes (Figure 4a, right) and opposite to elevation (Figure 4a, left). Therefore, soils in cluster II are largely considered highly productive and are located on slopes of low elevation, which are mainly in the southern half of the study area (Figure 1). Conversely, the lowest scores on this axis (Figure 4a, left) were for a group (cluster IV) of soils from low topographic locations (bottoms and certain slopes), mainly in the northern section of the studied area (Figure 1).

- Axis II had positive loadings (Figure 4a, top) for the variations in $\mathrm{pH}$, Ca, and $\mathrm{Mg}$ from the second to the third campaign. Rice cropping in 1990 and 2000 showed the largest loadings on axis II, which indicates that rice cropping was related to these variations. A sample (no. 7) located at the northernmost side of the study area and under rice in 1990 and 2000 had a notable score in this axis (Figure 4a, top), and formed a cluster of its own (cluster I).

- Axis III had positive loadings (Figure 4b, upper half) for all of the variations analyzed. A large group of soils (cluster III) was positioned at the negative part of this axis. This indicates that the soils in this cluster underwent no or only slight changes in salinity or alkalinity during the study periods.

Figure 5 presents the mean values of the soil solution composition for the clusters and shows the following different trends over the study period: (i) cluster I underwent a 
decrease in $\mathrm{pH}$ and an increase in $\mathrm{Ca}^{2+}$ and $\mathrm{Mg}^{2+}$ from the second to the third sampling;

370 (ii) the ionic concentration increased in the soils of cluster II from the first to the second campaign, but decreased in the third campaign back to levels similar or slightly higher than those at the beginning of the study, with an increase in pH-water; (iii) cluster III underwent a progressive decrease in salinity throughout the entire studied period and an increase in sodicity from the second to the third sampling campaign; and (iv) soil salinity decreased in cluster IV from the first to the second campaign and later increased from the second to the third campaign, often reaching values that were higher than those at the beginning of the first campaign.

\subsubsection{Main factors affecting the temporal changes}

The RDA of the temporal variations produced a statistically significant $(P<0.01)$ ordination model that included elevation $(P<0.01)$, rice cropping in $1990(P<0.05)$, and the location on slopes (landform unit type B) $(P<0.10)$ as explanatory variables. In spite of the low explained variance (16.9\%), this model was highly significant $(P<$ 0.001 for the first axis and for all the canonical axes).

\section{Discussion}

\subsection{Spatial variation of soil salinity}

Our results concerning the factors controlling the ionic composition of Flumen soils agree with previous studies of salinity in the central Ebro Valley (Badía et al., 2011; Herrero et al., 2011). These studies showed that, in most cases, the distribution of salinity under natural conditions is related to the location of the soil in the landscape, ranging from the platforms without salt-affected soils to the moderately to strongly saline soils in the bottoms.

Additionally, rice cropping showed a significant relationship with the ionic composition of the soil, which was linked to high sodicity $\left(\mathrm{HCO}_{3}{ }^{-}, \mathrm{pH}, \mathrm{SAR}\right)$. Rice is not salt-tolerant, but tilling and cropping paddies saturated with continuous flood irrigation water of very low salinity (Playán et al., 2008; Herrero and Hudnall, 2014) allows acceptable yields. Generally, rice cropping in Flumen is an indicator of salinity or salinity-sodicity because rice is the only profitable crop in these soils (Nogués et al., 
2000). However, rice planting expands to soils with higher percolation rates when prices increase (Herrero and Snyder, 1997).

\subsection{Temporal variation of salinity}

During the study period, the ionic composition of the analyzed soils changed over time, mainly due to increases and decreases in $\mathrm{Na}^{+}$and $\mathrm{Cl}^{-}$contents. Landscape units governed these variations, and our results highlight the salinity variations on the slopes. The construction of irrigated districts in the 1950s brought saliferous parent materials to the surface, making the slopes prone to salination (Herrero and Snyder, 1997). In the 1990s, the generalized use of sprinkling and other irrigation technologies stopped land leveling and replaced the traditional basin and border flood irrigation. This change in soil management is consistent with our results for the soils found on the slopes and the slope foothills of the southern area of the study. These soils, grouped in cluster II, underwent pronounced salination from the first to second campaigns and were related to land leveling. Between the second and third campaigns, these soils were desalinated with a slight sodication, which was attributed to the leaching of salts when using water of very low ionic content.

The soils of cluster IV, predominantly located in bottoms in the northern study area, followed the opposite trend. The salinity of these slightly or moderately saline soils decreased from the first to the second sampling campaign, but salinity rebounded from the second to the third campaign. This evolution can be attributed to a two-step process: first, irrigation with water of very low ionic content promoted the leaching of salts, and second, the water table rose as a result of overabundant irrigation, leading to a rebound in salinity. This explanation agrees with the magnitude of the irrigation return flows in this district and its impact on the volume and quality of the surficial waters (Isidoro and Aragüés, 2007; Martín-Queller et al., 2010). Under similar conditions,

425 Badía et al. (2011) recommended irrigating the soils of platforms and slopes with small water volumes at frequent intervals to decrease the hazard of water table rise and salination in the soils of the bottoms. However, the rise of water tables is not only dependent on the amount of water used for irrigation but also especially dependent on the irrigation system. For most crops in the area (excluding rice), the amount of water used for flood and sprinkler irrigation is quite similar $\left(3,500-10,000 \mathrm{~m}^{3} \mathrm{ha}^{-1} \mathrm{vs}\right.$. $3,000-$ 
$8,000 \mathrm{~m}^{3} \mathrm{ha}^{-1}$, respectively) but results in different contributions to the water table, since $37-41 \%$ of the water used for flood irrigation percolates into the ground compared to 026\% under sprinkler irrigation (Martínez et al., 2002). Herrero et al. (2003) reported that shallow water tables ( $<1.5 \mathrm{~m}$ depth) occur in the study area under flood irrigation, and rise to a 0.6-0.8 $\mathrm{m}$ depth during the irrigation season, leading to root zone salination of the affected soils.

The explanation is also compatible with desalination that occurred in the soils of cluster III from the first to the second campaign and from the second to the third campaign. This cluster is mainly populated by soils of the terraces, most of the soils from platforms, and the soils of many slopes from the northern area of the study. One interpretation is that these units were not affected by a rise in the water table, thus allowing a continuous leaching of salt to occur throughout the studied period of 1975 to 1999. Cluster III also included some paddies where salinity decreased as a result of the high doses of irrigation water, $\sim 15,000 \mathrm{~m}^{3} \mathrm{ha}^{-1}$ per year, producing significant desalination. A correlative increase of soil sodicity might occur, but the associated descent of soil permeability would not affect rice production in these inundated fields. Cluster III is the largest of the defined clusters, and its desalination trend agrees with the general trend reported by Herrero and Pérez-Coveta (2005) for the same period in the Flumen district.

We found the rice crop to be associated with a variation gradient that distinguished the soil at site no. 7 , due to its atypical evolution from the second to the third sampling campaign with a decrease in $\mathrm{pH}$, an increase in $\mathrm{Ca}^{2+}$, and a decrease in SAR. This evolution can be explained in puddled soils by the decomposition of straw, which releases $\mathrm{CO}_{2}$ and $\mathrm{Ca}^{2+}$ and decreased sodicity and $\mathrm{pH}$ (Bai et al., 2013). Irrespective of the mechanism of this atypical evolution in the study area, this result stresses the power of the MVA technique for detecting singular behaviors of small groups of observations or single cases.

From the environmental and management factors considered, elevation was found to have the highest explanatory power regarding the temporal variation in soil solution composition. Our results, specifically the spatial distribution of the clusters that mirror the temporal changes in salinity, suggest that, in this case, elevation is an indirect measure of a North-South spatial pattern. The southern district, which is located at a 
lower elevation, hosts more intense salination processes, while in the northern district these processes are milder. The most striking example of this difference is the severe salination of the soils on the slopes of the southern sector from the first to the second sampling campaign compared with the gentle and sustained desalination of the soils on the slopes in the northern area. Martín-Queller et al. (2010) and Jiménez et al. (2015) reached similar results when they studied the surface waters of the Flumen district, finding higher values for electrical conductivity, $\mathrm{Na}^{+}, \mathrm{Cl}^{-}, \mathrm{SO}_{4}{ }^{2-}$, and $\mathrm{NO}_{3}{ }^{-}$in the

470 southern area than in the northern area, which they mainly attributed to intense agricultural use in the southern part of the study area. Thus, our results add to other studies in elucidating the influence of agricultural management on temporal variations of salinity through the soil profile.

\section{Conclusions}

While the work by Herrero and Pérez-Coveta (2005) in the Flumen irrigation district reported on soil desalination from 1975 to 1999, the present article reveals the complexity of the changes in the salinity-sodicity of the soils. These changes differ and diverge depending on the considered sub-period, the location of the soil on the landscape, and the characteristics of the crops. The MVA of the ionic composition of the Flumen soils from 1975 to 1999 has identified several of these divergent processes. In general, temporal variations were related to irrigation, with incidences depending on the location in the district. Many soils on the slopes and foothills became salinated during the initial years due to land leveling, but salination eventually tapered off after sprinkler utilization. At high and middle elevations, most soils were slightly saline in the first campaign but underwent desalination during the study period. At lower elevations, an initial desalination was followed by a pronounced salination and was attributed to water table rise with generalized irrigation in the basin.

Sustainable agriculture in irrigated districts requires information about the salinity-sodicity of the soils and their trends, incorporating the many factors discussed above to reach sound interpretations. In this way, MVA, specifically direct gradient analyses, has performed well and has enormous potential coupled with a GIS treatment for analyzing soil salinity data. The use of MVA techniques in the present study elucidated the role of the studied explanatory factors in the spatial and temporal 
variation in soil salinity. However, the modest percent of the variances that were explained suggests that other non-considered environmental and management factors should be incorporated in future research studies. Multivariate analyses can improve our understanding of linkages between topographic controls and management practices on soil salinity to help inform future land management decisions.

\section{Acknowledgements}

This study was funded by the Spanish Government (project PCIN-2014-106). J.L. Mora also acknowledges support from the European Regional Fund and Aragón Regional Government through the PALEOQ (E56) research group.

\section{References}

Aguilera, H., Moreno, L., Jiménez-Hernández, M.E., Castaño, S., de la Losa, A., 2011. Management implications inferred from the multivariate analysis of vadose zone chemical variables in Las Tablas de Daimiel National Park (Spain). Geoderma, 162, 365377.

Akramkhanov, A., Martius, C., Park, S.J., Hendrickx, J.M.H., 2011. Environmental factors of spatial distribution of soil salinity on flat irrigated terrain. Geoderma, 163, 55-62.

Aldabaa, A.A.A., Weindorf, D.C., Chakraborty, S., Sharma, A., Li, B., 2015. Combination of proximal and remote sensing methods for rapid soil salinity quantification. Geoderma $515 \quad$ 239-240, 34-46.

Álvarez Rogel, J., Ortiz Silla, R., Alcaraz Ariza, F., 2001. Edaphic characterization and soil ionic composition influencing plant zonation in a semiarid Mediterranean salt marsh. Geoderma, 99, 81-98.

Amezketa, E., 2007. Use of an electromagnetic technique to determine sodicity in saline-sodic soils. Soil Use and Management, 23, 278-285.

Ammari, T.G., Tahhan, R., Abubaker, S., Al-Zu’bi, Y., Tahboub, A., Ta’any, R., Abu-Romman, S., Al-Manaseer, N., Stietiya, M.H., 2013. Soil salinity changes in the Jordan Valley potentially threaten sustainable irrigated agriculture. Pedosphere, 23, 376-384.

Ayers, R.S., Westcot, D.W., 1994. Water quality for agriculture. FAO Irrigation and Drainage Paper 29. FAO, Rome

Badía, D., Martí, C., Poch, R.M., 2011. A soil toposequence characterization in the irrigable lands - protected area contact zone of El Basal, NE Spain. Arid Land Research and Management, 25, 1-18.

Bai, Y., Gu, C., Tao, T., Chen, G., Shan, Y., 2013. Straw incorporation increases solubility and uptake of cadmium by rice plants. Acta Agriculturae Scandinavica, Section B - Soil \& Plant Science, 63, 193-199.

Barbiéro, L., Mohamedou, A.O., Laperrousaz, C., Furian, S., Cunnac, S., 2004. Polyphasic origin of salinity in the Senegal delta and middle valley. Catena, 58, 101-124.

Corwin, D.L., 2008. Past, present, and future trends of soil electrical conductivity measurements using geophysical methods. In: Handbook of Agricultural Geophysics (eds. B. Allred, J.J. Daniels, M.R. Ehsani), CRC Press New York USA, pp. 17-44. 
Corwin, D.L., 2012. Field-scale monitoring of the long-term impact and sustainability of drainage water reuse on the west side of California's San Joaquin Valley. Journal of Environmental Monitoring, 14, 1576-1596.

540 Domínguez-Beisiegel, M., Castañeda, C., Mougenot, B., Herrero, J., 2016. Analysis and mapping of the spectral characteristics of fractional green cover in saline wetlands (NE Spain) using field and remote sensing data. Remote Sensing, 8(7), 590; DOI:10.3390/rs8070590.

Dou, C.Y., Kang, Y.H., Wan, S.Q., Hu, W., 2011. Soil salinity changes under cropping with Lycium barbarum L. and irrigated with saline-sodic water. Pedosphere, 21, 539-548.

Hair, J.F., Black, W.C., Babin, B.J., Anderson, R.E., 2010. Multivariate data analysis. Prentice Hall, Englewood Cliffs.

Herrero, J., 1987. Tendencias de salinidad en suelos del sistema de riegos Monegros-Flumen. In: $7^{\mathrm{a}}$ Conferencia sobre Hidrología General y Aplicada, SMAGUA Zaragoza, pp. 411421

Herrero, J., Hudnall, W.H., 2014. Measurement of soil salinity using electromagnetic induction in a paddy with a densic pan and shallow water table. Paddy and Water Environment, 12, 263-274.

Herrero, J., Pérez-Coveta, O., 2005. Soil salinity changes over 24 years in a Mediterranean irrigated district. Geoderma, 125, 287-308.

Herrero, J., Snyder, R.L., 1997. Aridity and irrigation in Aragon, Spain. Journal of Arid Environments, 35, 535-547.

Herrero, J., Ba, A.A., Aragüés, R., 2003. Soil salinity and its distribution determined by soil sampling and electromagnetic techniques. Soil Use and Management 19, 119-126.

560 Herrero, J., Netthisinghe, A., Hudnall, W.H., Pérez-Coveta, O., 2011. Electromagnetic induction as a basis for soil salinity monitoring within a Mediterranean irrigation district. Journal of Hydrology, 405, 427-438.

Isidoro, D., Aragüés, R., 2007. River water quality and irrigated agriculture in the Ebro basin: an overview. International Journal of Water Resources Development, 23, 91-106.

565 IUSS Working Group WRB. 2014. World Reference Base for Soil Resources 2014. World Soil Resources Reports No. 106. FAO, Rome.

Jiménez, J.J., Darwiche-Criado, N., Sorando, R., Comín, F.A., Sánchez-Pérez, J.M., 2015. A methodological approach for spatiotemporally analyzing water-polluting effluents in agricultural landscapes using partial triadic analysis. Journal of Environmental Quality, $570 \quad 44,1617-1630$.

Johansson, M., Stenberg, B., 2000. Multivariate techniques for presentation, interpretation and evaluation of soil quality data, in: Elmholt, S., Stenberg, B., Grønlund, A., Nuutinen, V. (Eds.), Soil Stresses, Quality and Care. DIAS Report 38. DIAS, Tjele, pp. 63-72.

Legendre, P., Legendre, L. F., 2012. Numerical Ecology, Third English Edition. Elsevier Oxford UK.

MAPA., 1974. Official Analysis Methods: Soils and Water. Ministerio de Agricultura, Pesca y Alimentación, Madrid Spain

MAPA., 1994. Official Analysis Methods. Vol. III. Ministerio de Agricultura, Pesca y Alimentación, Madrid Spain.

580 Martín-Queller, E., Moreno-Mateos, D., Pedrocchi, C., Cervantes, J., Martínez, G., 2010. Impacts of intensive agricultural irrigation and livestock farming on a semi-arid Mediterranean catchment. Environmental Monitoring and Assessment, 167, 423-435.

Martínez, Y., Uku, S., Albiac, J., 2002. El control de la contaminación por nitratos en el regadío. Economía Agraria y Recursos Naturales, 2, 115-131.

Martínez-Cob, A., Faci, J.M., Bercero, A., 1998. Evapotranspiración y necesidades de riego de los principales cultivos en las comarcas de Aragón. Institución Fernando el Católico, Zaragoza. Spain.

Metternicht, G., Zinck, J.A., 2009. Remote Sensing of Soil Salinization: Impact on Land Management. CRC Press Boca Raton FL USA.

Mora, J.L., Arbelo, C, Armas, C., Guerra, A., Rodríguez-Rodríguez, A., 2005. Salinity and alkalinity in soils of the arid region of Tenerife, Canary Islands, Spain. In: Sustainable 
Use and Management of Soils - Arid and Semiarid Regions (eds. Á. Faz, R. Ortiz, A.R. Mermut), Advances in Geoecology 36, Catena-Verlag Reiskirchen Germany, pp. 23-32.

Nogués, J., Herrero, J., 2003. The impact of transition from flood to sprinkler irrigation on water district consumption. Journal of Hydrology, 276, 37-52.

Nogués, J., Herrero, J., Rodríguez-Ochoa, R., Boixadera, J., 2000. Land evaluation in a saltaffected irrigated district using an index of productive potential. Environmental Management, 25, 143-152.

600

Pisinaras, V., Tsihrintzis, V.A., Petalas, C., Ouzounis, K., 2010. Soil salinization in the agricultural lands of Rhodope District, northeastern Greece. Environmental Monitoring and Assessment, 166, 79-94.

Playán, E., Pérez-Coveta, O., Martínez-Cob, A., Herrero, J., García-Navarro, P., Latorre, B., Bufau, P., Garcés, J., 2008. Overland water and salt flows in a set of rice paddies. Agricultural Water Management, 95, 645-658

605 Rhoades, J.D., Lesch, S.M., LeMert, R.D., Alves, W.J., 1997. Assessing irrigation/drainage/salinity management using spatially referenced salinity measurements. Agricultural Water Management, 35, 147-165.

Rodríguez Rodríguez, A., Mora, J.L., Arbelo, C., Bordón, J., 2005. Plant succession and soil degradation in desertified areas (Fuerteventura, Canary Islands, Spain). Catena, 59, 117610131

Rukhovich, D.I., Koroleva, P.V., Vil'chevskaya, Y.V., Kalinina, N.V., Chernousenko, G.I., Rukhovich, S.V., 2013. Spatial variability of soil salinization as judged from the comparison of soil maps and remote sensing materials for different years in Uzbekistan. In: Developments in Soil Salinity Assessment and Reclamation (eds. S.A. Shahid, M.A. Abdelfattah, F.K. Taha), Springer Dordrecht, pp. 127-139.

Shahid, S.A., 2013. Developments in soil salinity assessment, modeling, mapping, and monitoring from regional to submicroscopic scales. In: Developments in Soil Salinity Assessment and Reclamation (eds. S.A. Shahid, M.A. Abdelfattah, F.K. Taha), Springer Dordrecht The Netherlands, pp. 3-43.

620 Swanhart, S., Weindorf, D.C., Chakraborty, S., Bakr, N., Zhu, Y., Nelson, C., Shook, K., Acree, A., 2014. Soil salinity measurement via portable x-ray fluorescence spectrometry. Soil Science 179, 417-423.

Tug, G.N., Ketenoglu, O., Bilgin, A., 2012. The relationships between plant zonation and edaphic factors in halophytic vegetation around Lake Tuz, Central Anatolia, Turkey. Rendiconti Lincei, 23, 355-363.

United States Salinity Laboratory Staff. 1954. Diagnosis and Improvement of Saline and Alkali Soils. USDA Handbook No. 60, USDA Washington DC USA.

Young, A., 1991. Soil monitoring: a basic task for soil survey organizations. Soil Use and Management, 7, 126-130.

630 Young, F.J., Hammer, R.D., 2000. Defining geographic soil bodies by landscape position, soil taxonomy, and cluster analysis. Soil Science Society of America Journal, 64, 989-998. 
Figure 1. Sampling sites location, landform units, and clustering based on temporal variations of salinity. Black arrows show the flow direction of rivers and channels.

Figure 2. Frequency distributions of the comparable values of ECe, (a), SAR (b), and $\mathrm{pH}$ (c), in the three soil campaigns.

Figure 3. Biplot diagram of the first and second (a), and of the third and fourth (b) axes obtained from the principal components analysis (PCA) of the soil solution data.

The cross-marks represent the soil ionic components during the first, second, and third sampling campaigns, and the individual soils are represented with symbols depending on the landform unit type. Other environmental and management factors are displayed as arrows.

Figure 4. Biplot diagram of the first and second (a), and of the first and third (b) axes obtained from the principal components analysis (PCA) of the temporal variations of the soil solution data during the study period.

The cross-marks represent the variations in the soil ionic components from the first to the second sampling campaigns, and from the second to the third sampling campaigns. The variations occurred from the first to the third campaign are indicated with $\mathrm{x}$-marks. The individual soils are represented with symbols depending on their membership to clusters with differing temporal variations during the study period. Supplementary (environmental and management) variables are displayed as arrows. $\mathrm{A}=$ Platforms; $\mathrm{B}=$ Slopes, $\mathrm{C}=$ Terraces, and $\mathrm{D}=$ Bottoms.

Figure 5. Mean values ( \pm SEM) of the soil solution data in clusters of points with differing temporal variations during the study period. 
660 Table 1. Main landform units and WRB soil types in the study area (adapted from Nogués and Herrero, 2003)

Units Landform units

Main soil types (IUSS Working Group WRB, 2014)

A.1 Structural platforms of $\quad$ Eutric Regosols with inclusions of Eutric Leptosols sandstone and lutite

A.2 Residual platforms with coarse detrital sediments

Haplic Calcisols with inclusions of Petric Calcisols

B.1 Glacis slopes on fine

Association of Eutric Fluvisols and Eutric detrital sediments

Regosols, with inclusions of Haplic Solonetzs and Fluvic Cambisols

B.2 Other slopes on fine detrital sediments

Association of Eutric Fluvisols and Eutric Regosols, with inclusions of Haplic Solonetzs and Haplic Calcisols

C.1 Flumen and Alcanadre Association of Eutric Fluvisols and Eutric Regosols rivers terraces on fine detrital sediments

C.2 Flumen terrace on fine detrital sediments

Association of Eutric Fluvisols and Eutric Regosols

C.3 Flumen terrace on fine detrital sediments

Haplic Solonchaks

C.4. Flumen terrace

Eutric Fluvisols

D Bottoms on fine detrital

Association of Gleyic and Gleyic-Fluvic sediments

Solonchaks; with inclusions of Salic Solonetzs, Eutric Regosols and Gleyic Cambisols 
Table 2. Analytical methods used in 1975, 1985/1986, and 1999

\begin{tabular}{|c|c|c|c|}
\hline & 1975 & $1985 / 86$ & 1999 \\
\hline $\begin{array}{l}\mathrm{pH}- \\
\text { water, } \\
\mathrm{pH}-\mathrm{KCl}\end{array}$ & $\begin{array}{l}\text { Unknown } \\
\text { soil:water } \\
\text { ratio }\end{array}$ & 1:2.5 soil:water ratio & 1:2.5 soil:water ratio \\
\hline ECe & $\begin{array}{l}\text { Saturated } \\
\text { paste }\end{array}$ & Saturated paste & Saturated paste \\
\hline $\mathrm{Cl}^{-*}$ & Unknown & Potentiometric titration & \multirow{2}{*}{$\begin{array}{l}\text { Ionic cromatography with a } \\
\text { Dionex 2000i/SP (Dionex, } \\
\text { Sunnyvale, CA, USA) }\end{array}$} \\
\hline $\mathrm{SO}_{4}{ }^{2-*}$ & $\begin{array}{l}\text { Not } \\
\text { analyzed }\end{array}$ & $\begin{array}{l}\text { Turbidometry with a Beckman } \\
24 \quad \text { spectrophotometer } \\
\text { (Beckman Coulter, Fullerton, } \\
\text { CA, USA) }\end{array}$ & \\
\hline $\mathrm{HCO}_{3}{ }^{-*}$ & $\begin{array}{l}\text { Not } \\
\text { analyzed }\end{array}$ & Potentiometric titration & Potentiometric titration \\
\hline $\mathrm{Na}^{+*}$ & Unknown & Flame photometry & \multirow{2}{*}{$\begin{array}{l}\text { Atomic absortion } \\
\text { spectrometry with a Perkin- } \\
\text { Elmer 30303 (Perkin-Elmer } \\
\text { Wellesley, MA, USA) }\end{array}$} \\
\hline $\begin{array}{l}\mathrm{Ca}^{2+} \\
\mathrm{Mg}^{2+*}\end{array}$ & $\begin{array}{l}\text { Unknown } \\
\text { (jointly) }\end{array}$ & EDTA titration & \\
\hline
\end{tabular}

${ }^{*}$ The ionic contents were determined in saturated paste extracts 